\title{
Management of Meloidogyne incognita by Pseudomonas fluorescens and Trichoderma viride in mulberry
}

\author{
M. MUTHULAKSHMI* AND K. DEVRAJAN
}

Department of Nematology, Tamil Nadu Agricultural University, COIMBATORE (T.N.) INDIA

\section{ARITCLE INFO}

Received : 29.09 .2014

Revised : 01.01 .2015

Accepted : 15.01 .2015

\section{KEY WORDS :}

Biological control, Morus alba, Rootknot nematode, $P$. fluorescens, $T$. viride

*Corresponding author:

Email: lakshminem@gmail.com

\begin{abstract}
The efficacy of commercial formulations of the plant growth promoting rhizobacterium Pseudomonas fluorescens and the antagonistic fungus Trichoderma viride on the root-knot nematode, Meloidogyne incognita, infesting mulberry, Morus alba, were evaluated under field conditions. The effects of applications to the soil of formulations of the bio-control agents, alone and in combination at the rates of 3 and $6 \mathrm{~g} / \mathrm{plot}$, were compared with those of the nematicide carbofuran $3 \mathrm{G}$ at the rate of $1 \mathrm{~kg}$ a.i./ha and controls. The combination of $P$. fluorescens $(6 \mathrm{~g} / \mathrm{plot})$ and $T$. viride $(6 \mathrm{~g} / \mathrm{plot})$ was effective in reducing the population of $M$. incognita in soil and root and suppressing root-galling of mulberry. This treatment also improved shoot and root development and increased leaf area, leaf contents of protein, nitrogen and chlorophyll, silkworm larval weight, cocoon weight, shell weight and shell ratio of silkworm larvae fed on leaves of mulberry infested with $M$. incognita.
\end{abstract}

How to view point the article : Muthulakshmi, M. and Devrajan, K. (2015). Management of Meloidogyne incognita by Pseudomonas fluorescens and Trichoderma viride in mulberry. Internat. J. Plant Protec., 8(1) : 1-6. 